\title{
TOWNSHIP LEASES AND ECONOMIC DEVELOPMENT IN NORTHERN TERRITORY ABORIGINAL COMMUNITIES
}

\author{
LEON TERRILL*
}

\section{INTRODUCTION}

Indigenous policy in Australia has changed a great deal over the last two decades. One of the more significant changes has been an increased focus on economic development and participation in the 'mainstream economy'. It is in this context that the Australian government promotes the adoption of township leases by Aboriginal communities in the Northern Territory, a reform introduced by the Howard government in 2006 following a contentious debate about communal ownership of Indigenous land. In the period since, governments of both persuasions have put considerable effort and resources into the reforms and numerous reports have described a need for further township leases so as to 'facilitate better economic development and home ownership outcomes for residents'. ${ }^{1}$ The current Minister for Indigenous Affairs, Nigel Scullion, goes so far as to argue that township leasing 'has brought about change unlike any seen before in remote Aboriginal communities'. ${ }^{2}$ Pointing to developments in Wurrumiyanga, the first township lease community, he reports that it is 'the first time we have seen local ownership of homes and businesses on this scale in an Aboriginal community in the Northern Territory'. ${ }^{3}$

This article considers the true impact of township leasing on economic activity in Aboriginal communities. Taking Wurrumiyanga as a case study, it tests the government's claim that township leases bring about unprecedented change. It also clarifies the particular way in which township leasing has altered the economic circumstances of communities and describes how this compares to alternative approaches. For there is more than one way in which reforms to land tenure might attempt to support economic development in communities on Aboriginal land. Like many other areas of policy, there will be competing views about when, or whether, reform is necessary, and about which reform is best. It is inevitable that any approach will result in winners and losers. The article attempts to set out the options in a way that enables informed discussion about their consequences. This is relevant not just to township lease communities, but

* Senior Lecturer, Faculty of Law, University of New South Wales.

1 Australian Government, 'Our North, Our Future: White Paper on Developing Northern Australia' (2015) 32 .

2 Nigel Scullion, 'Reform for the Future', Koori Mail (Lismore), 26 March 2014, 24.

3 Ibid 
to all residential communities on Indigenous land in Australia where land tenure reform is being considered. ${ }^{4}$

It is argued here that for residential communities on Indigenous land there is a choice, and often a tension, between two basic approaches to reform, which are described here as a landowner-driven approach and an occupier-driven approach. In short, under a landowner-driven approach, reforms are introduced in a way that maximises financial returns for the underlying landowners, which in the Northern Territory is usually the traditional owners for that particular country. Under an occupier-driven approach, the focus is instead on providing occupiers with a set of property rights that best enable them to engage in economic activity. A fuller explanation of these terms, and of the relationship between landowners and occupiers, is provided in Part II.

For the most part, township leasing — in common with most other recent reforms - has implemented a landowner-driven approach to reform. This has ongoing consequences for relationships, governance and economic activity in those communities. Once implemented, it is very difficult to switch from one approach to the other. Due to the way in which Indigenous land reform has been debated in Australia, there has been almost no discussion of the benefits and risks of each approach.

This article is partly a corrective. In its publications, the Australian government routinely suggests that township leases implement an occupier-driven approach to development. For example, the Closing the Gap Report for 2016 states that:

Township leases are a lever for economic development, delivering long-term tradeable tenure to underpin commercial activities and home ownership. They simplify leasing and land use across a whole town and makes it possible for individuals to obtain long-term subleases to support a loan. ${ }^{5}$

Below, it is explained why such statements are so misleading. The primary economic impact of existing township leases has been to create a revenue stream for the underlying landowners through rent on subleases. The introduction of 'long-term tradeable tenure', or of individuals obtaining 'long-term subleases to support a loan', has been the rare exception and certainly not the norm.

Beyond this, the article is also an attempt to reframe discussion about tenure reform in communities on Indigenous land in a manner that is accurate and accessible, and aids with the task of understanding the real issues that arise. From the beginning, debate about township leasing — and Indigenous land reform

4 The term 'land tenure reform' is used here to describe changes to the legal arrangements for the ownership and use of land. Other names include 'land reform' and 'land policy reform'. Over the last decade, Australian governments - led primarily by the Commonwealth - have introduced several sets of land tenure reform in residential communities on Indigenous land. Township leasing is one of those reforms; others include the 40-year housing precinct leases, 'secure tenure' policies and the fiveyear leases introduced as part of the Northern Territory Emergency Response. A recent description of those reforms is provided in Leon Terrill, Beyond Communal and Individual Ownership: Indigenous Land Reform in Australia (Routledge, 2016).

5 Department of the Prime Minister and Cabinet, 'Closing the Gap: Prime Minister's Report 2016' (2016) 39. 
more generally — has been highly politicised, which has often led to issues being presented and contested in abstract terms. This article instead tries to make clear the day-to-day impact of the reforms and what is particular about the way they have been implemented. To that end, it introduces some concepts and explanatory devices that have not been used previously. ${ }^{6}$ When the article returns to a broader discussion of the consequences of reform, it describes how the issues do not fall along neat ideological lines.

The next section - Part II — sets out the background to the reforms by describing the circumstances of communities on Aboriginal land historically and what this means for the introduction of land reform. It also introduces the concept of a 'leasehold spectrum' to clarify the available options when granting formal rights to occupiers. Part III describes outcomes under the township lease in Wurrumiyanga, and clarifies the particular way in which subleases have been granted. Part IV teases out some of the consequences of taking a landowner-driven or occupier-driven approach. Part V then provides a discussion, addressing such questions as which approach is likely to lead to greater economic development, how issues of cultural compatibility arise and the likely impact of reforms on the balance of relationships in communities on Aboriginal land.

\section{BACKGROUND TO THE REFORMS}

\section{A Communities on Aboriginal land}

Consider the following scenario: a residential community of a few hundred mostly Aboriginal people is situated on Aboriginal land. The land itself is owned by a legal entity called a 'Land Trust', which holds title on behalf of those Aboriginal people whose land it is under traditional law. ${ }^{7}$ This group is known as the 'traditional Aboriginal owners' and it contains a combination of senior and more junior members. As people are born, grow up and die, the membership and dynamics of the ownership group change. Importantly, not all Aboriginal people who live in the community are necessarily traditional Aboriginal owners for that particular land. While it may be their home, in many communities there will be Aboriginal residents who are not regarded as being members of the traditional landowning group. ${ }^{8}$

6 It is noted that residential communities (also called settlements or townships) are a special case, in that the matters that need to be addressed are slightly different to those affecting Indigenous land outside of communities. The concepts developed by the article are intended for communities and not those other areas of Indigenous land.

7 This is a simplification. Land under the Aboriginal Land Rights (Northern Territory) Act 1976 (Cth) ('ALRA') operates under a 'tripartite structure', which also includes Aboriginal land councils: see Sean Brennan, 'Wurridjal v Commonwealth: The Northern Territory Intervention and Just Terms for the Acquisition of Property' (2009) 33 Melbourne University Law Review 957, 960. An effort is being made here to avoid embroiling the reader in unnecessary detail.

8 The relationship between residence and traditional ownership is complex and is discussed further in Part III. 
In addition to housing, the community itself contains such services as a school, council office and aged care facility and a few small-scale enterprises such as a store, an art centre and visitor accommodation. All of the buildings in the community have been allocated to particular organisations and families, referred to in this article as the 'occupiers', but for historic reasons the arrangements for doing so are informal. That is, most occupiers have never applied for or been granted a set of formal rights such as a lease, and no other legal mechanisms have been developed to formalise their rights.

This, in simplified form, describes the situation in most communities on Aboriginal land ${ }^{9}$ in the Northern Territory prior to the introduction of reforms such as township leasing over the last decade. The actual make-up of communities varies considerably, not least with respect to size and the range of facilities that have been built. However, the practice of using informal arrangements to allocate land and infrastructure has been widespread, not just in the Northern Territory but in communities on Indigenous land around Australia. ${ }^{10}$

The effect of reforms such as township leasing has been to formalise the rights of occupiers in these communities. There are several ways in which this can be done and a key question becomes: how can tenure arrangements be formalised so as to best support economic development? This is not the only issue that arises: others include governance, the protection of vulnerable groups in the reform process, addressing the impact of historical displacement and the impact of new arrangements on existing cultural practices. Some of those issues have been addressed elsewhere; ${ }^{11}$ the focus of this article is economic development.

\section{B The Problem with a Dualistic Approach to Debate}

To its detriment, debate about Indigenous land reform in Australia has often been framed in terms of dualisms. The most common has been the use of terms such as 'communal ownership' to describe existing arrangements and 'individual ownership' or 'private property' to describe the intended outcome of land reform. This was particularly common when township leasing was first

9 This description refers to communities on land held under the $A L R A$, which is by far the most widespread form of Aboriginal land in the Northern Territory and the land on which most residential communities are situated. It is also residential communities on ALRA land that are the target of township leasing: see Part III A below.

10 Particularly in Queensland and South Australia: see Tom Calma, 'Native Title Report 2009' (Report No 2/2010, Australian Human Rights Commission, 2009) 166-78. Over the last 10 years, as a result of government-led reforms, leases have become more common.

11 See ibid 133-42; Sean Brennan, 'Economic Development and Land Council Power: Modernising the Land Rights Act or Same Old Same Old?' (2006) 10(4) Australian Indigenous Law Reporter 1; Terrill, Beyond Communal and Individual Ownership, above n 4, ch 7. 
introduced in $2006,{ }^{12}$ but at times also continues today. For example, one of the core recommendations of the Forrest Review in 2014 was to enable 'individual ownership of land' as 'individual land title underpins all advanced economies'. ${ }^{13}$ In 2015, the White Paper on Developing Northern Australia spoke of the need to 'increase individual property rights in township areas for willing Indigenous communities'. ${ }^{14}$

A slightly different dualism has been used by the Australian government as a type of explanatory device. In the course of describing why Indigenous land reform is necessary, it has often referred to a need for 'secure tenure'. The existing arrangements, it has argued, failed to provide for 'secure tenure', whereas land reform will enable it. While it has never provided a clear explanation of what 'secure tenure' means, the government has attributed a wide range of benefits to its introduction, including greater investment. ${ }^{15}$

One problem with this dualistic approach to debate is that it suggests that the existing arrangements are uniform and that there is a single and obvious reform outcome. Neither is true. Historically, arrangements have varied between different types of infrastructure, as well as between land inside of residential communities and other areas of Aboriginal land. For example, the arrangements with respect to a police station or school in an Aboriginal community were different to those with respect to housing for Aboriginal residents. ${ }^{16}$ And far from there being a single model of reform, tenure arrangements can be altered and formalised in any number of different ways. As this article illustrates, land reform involves a series of complex decisions.

A further problem with this terminology is the extent to which it can mislead. References to the introduction of 'individual ownership' suggest a move towards ownership of property by individuals, which has been extremely rare. The majority of leases and subleases created as a result of recent reforms have been granted to government agencies, shire councils and non-government organisations. This development is not well captured by references to either 'individual ownership' or 'secure tenure'.'

The more accurate terminology is that of 'formalisation', however this too has limitations. Employed simply, it might also suggest a dualism — whereby formal tenure is good and informal tenure is bad, or vice versa. Used more broadly it

12 The debate is described at: Terrill, Beyond Communal and Individual Ownership, above n 4, 12848; Stuart Bradfield, 'White Picket Fence or Trojan Horse? The Debate over Communal Ownership of Indigenous Land and Individual Wealth Creation.' (Issues Paper Volume 3 No 3, Native Title Research Unit, Australian Institute of Aboriginal and Torres Strait Islander Studies, June 2005); Michael Dodson and Diana McCarthy, 'Communal Land and the Amendments to the Aboriginal Land Rights Act (NT)' (Research Discussion Paper No 19, Native Title Research Unit, Australian Institute of Aboriginal and Torres Strait Islander Studies, 2006); Tom Calma, 'Native Title Report 2007' (Report No 2/2008, Human Rights and Equal Opportunity Commission, 2008) chs 1, 2.

13 Andrew Forrest, 'The Forrest Review: Creating Parity' (Commonwealth of Australia, 2014) 2, 52.

14 Australian Government, 'Our North, Our Future', above n 1, 15.

15 Terrill, Beyond Communal and Individual Ownership, above n 4, 149-51.

16 Ibid 105-10.

17 Ibid 204-6. 
is very open, in that formalisation can take so many different forms that little clarity is conveyed by descriptions of a shift to more formal tenure. So how to meaningfully and helpfully describe the choices that are available?

To begin, there are two main decisions to be made when introducing formal tenure arrangements in a community on Aboriginal land: to whom the grant of formal tenure is made, and on what terms. The first requires little explanation; it simply refers to the identity of the people or organisations who are granted the formal rights. The second of these decisions, the terms upon which grants are made, is a little more complicated and the next section clarifies the range of options.

\section{The Leasehold Spectrum}

In addition to Aboriginal residents (some of whom are traditional owners, others of whom are not), larger residential communities on Aboriginal land typically contain a variety of organisations such as government departments and agencies, service-providing NGOs and small-scale enterprises such as a corporation owning the community store. ${ }^{18}$ An important issue when formalising tenure arrangements in communities is the extent to which there is a transfer of formal property rights from the underlying landowners to each occupier. There can be a complete transfer, where land is divided up into portions and occupiers are granted freehold ownership of each lot. Or there can be a more contained transfer, where occupiers are granted a lease or sublease. In 2014, the Queensland government introduced legislation that enables some Indigenous land in that state to be divided up and converted to ordinary freehold. ${ }^{19}$ That legislation only commenced in 2015 and has not yet been used, and there is no equivalent in other Australian jurisdictions. To date, the preferred approach has been to formalise tenure arrangements through leases and subleases. This avoids having to extinguish underlying ownership of land by the Indigenous group, which has been an issue of significant concern for many Indigenous people.

Electing to use leasehold rather than freehold is not the end of the matter as leases and subleases vary considerably with respect to the extent they convey rights to the occupier. In the Australian Capital Territory, for example, the Crown retains underlying title and 'landowners' are granted long-term, transferable leases. ${ }^{20}$ Those leases are then bought, sold and mortgaged in a very similar manner to freehold. At the other end of the scale are leases such as a residential tenancy or a short-term retail lease, where the rights granted to the tenant are far more limited.

Clearly, the way in which leases are drafted will have an impact on how economic development occurs. To illustrate the range of options available here, this article

18 Diagram Three below provides a description of occupiers in the community of Wurrumiyanga.

19 See Aboriginal and Torres Strait Islander Land (Providing Freehold) and Other Legislation Amendment Act 2014 (Qld).

20 Landownership in the ACT is described in House of Representatives Standing Committee on Transport, Communications and Infrastructure, Parliament of Australia, Report on the Canberra Leasehold System (November 1988). 
identifies five key variables that impact on economic development and plots them on a device called a 'leasehold spectrum'. The five variables are the duration of the lease; the amount of ongoing rent; its transferability; what restrictions there are on the use of the land; and the circumstances in which the sublease can be forfeited or cancelled. The range of options with respect to those variables is depicted in Diagram One.

Diagram One: The leasehold spectrum

\begin{tabular}{|c|c|c|c|}
\hline Duration & $\begin{array}{l}\text { Short } \\
\text { term }\end{array}$ & $\longleftrightarrow$ & $\begin{array}{l}\text { Long } \\
\text { term }\end{array}$ \\
\hline $\begin{array}{l}\text { Ongoing } \\
\text { rent }\end{array}$ & Market rent & $\longleftrightarrow$ & No rent \\
\hline Transferability & No transfer & $\stackrel{\square}{\longleftrightarrow}$ & $\begin{array}{l}\text { Freely } \\
\text { transferable }\end{array}$ \\
\hline Restrictions & Many restrictions & $\stackrel{\longleftrightarrow}{\longleftrightarrow}$ & No restrictions \\
\hline Forfeiture & Readily cancelled & $\longleftrightarrow$ & $\begin{array}{l}\text { Can't be } \\
\text { cancelled }\end{array}$ \\
\hline
\end{tabular}

It is described as a spectrum because in each case there is a range of possibilities. The duration might be from a week or a year through to 99 years. The amount of ongoing rent can be zero, ${ }^{21}$ nominal, subsidised or market rent. ${ }^{22}$ There may be a clause prohibiting transfer of the lease, providing that it can only be transferred to certain persons, or with consent, or allowing it to be transferred to anyone. There can be a long list of other restrictions on the way the subject land can be used, or none at all. And a lease can be drafted such that a breach of its terms can readily result in the cancellation of the lease, or in a way that makes cancellation by the lessor difficult or impossible.

The leasehold spectrum depicts these five variables in a manner that also gives an indication as to their economic consequences. The further to the right, for each variable, the greater the transfer of rights from the landowner to the occupier. The further to the left, the greater the extent to which the underlying landowners have held onto their rights.

This is a useful point to consider the difference between granting occupiers a lease and granting freehold, as can occur under the legislation recently introduced in Queensland. Of its nature, freehold (or a fee simple, the most common form of freehold) has certain fixed characteristics - it is perpetual, no ongoing rent is paid to the former owner, it is freely transferable, unrestrictive ${ }^{23}$ and cannot be forfeited. There is no freehold equivalent to the leasehold spectrum; all fee simple

21 While it is more common for rent to be nominal rather than zero, rent-free leases and subleases are permitted by law: Peter Butt, Land Law (Lawbook Co, $6^{\text {th }}$ ed, 2010) 276.

22 The term 'market rent' is being used here broadly, in that in most remote Aboriginal communities there is no conventional market for land, rather a single landowner setting the rent for all properties in the community.

23 Freehold can be subject to restrictions in the form of freehold covenants / restrictive covenants. Freehold covenants are relatively uncommon. There are also limits on the matters they may address: see Butt, above n 21, ch 17. 
ownership tends to have the same features. ${ }^{24}$ This is illustrated in Diagram Two, which compares the range of outcomes that are available under leasehold with the fixed outcomes that occur under a fee simple. Depending on the desired outcome, this flexibility can be a potential advantage of using leasehold ownership. ${ }^{25} \mathrm{~A}$ lease can range from being short-term and restrictive, through to something that approximates freehold ownership, depending on the economic model being implemented.

\section{Diagram Two: Leasehold and freehold compared}

\begin{tabular}{|c|c|c|c|c|}
\hline \multirow{2}{*}{ Duration } & \multicolumn{3}{|c|}{ The leasehold spectrum } & \multirow{2}{*}{$\begin{array}{l}\text { Freehold } \\
\text { Perpetual }\end{array}$} \\
\hline & $\begin{array}{l}\text { Short } \\
\text { term }\end{array}$ & $\longleftrightarrow$ & $\begin{array}{l}\text { Long } \\
\text { term }\end{array}$ & \\
\hline $\begin{array}{l}\text { Ongoing } \\
\text { Rent }\end{array}$ & Market rent & $\longleftrightarrow$ & No rent & No rent \\
\hline Transferability & No transfer & $\longleftrightarrow$ & $\begin{array}{l}\text { Freely } \\
\text { transferable }\end{array}$ & $\begin{array}{l}\text { Freely } \\
\text { transferable }\end{array}$ \\
\hline Restrictions & $\begin{array}{l}\text { Many } \\
\text { restrictions }\end{array}$ & $\longleftrightarrow$ & No restrictions & No restrictions \\
\hline Forfeiture & $\begin{array}{l}\text { Readily } \\
\text { cancelled }\end{array}$ & $\longleftrightarrow$ & $\begin{array}{l}\text { Can't be } \\
\text { cancelled }\end{array}$ & $\begin{array}{l}\text { Can't be } \\
\text { cancelled }\end{array}$ \\
\hline
\end{tabular}

Naturally, the form of ownership that any occupier would prefer is freehold ownership or a freehold-like lease. From the perspective of the landowning group, the reverse applies. Under a lease towards the left of the spectrum, they retain ongoing control and receive ongoing rent. In mature land markets, parties negotiate the form of grant they are willing to agree upon. If that is freehold or a freehold-like lease then the purchaser will normally have to pay a purchase price, reflecting the greater value to them of the grant. It is different in communities on Indigenous land. In most communities, there is a single landholding body (such as an Aboriginal land trust or, where there is a township lease, the Executive Director of Township Leasing) that determines the terms upon which grants are made to occupiers. The spectrum illustrates, in a simplified form, the options that are open to them, in a way that gives some indication of what this will mean for economic activity.

This also helps clarify what is meant by the distinction between a landownerdriven and occupier-driven approach to economic development. Under a landowner-driven approach, the focus is on obtaining an economic return for the landowners, especially ongoing rent — in other words, a lease (or sublease) that

24 An important exception to this is strata title, under which the fee simple owners of units are often subject to a variety of restrictions. To the author's knowledge, strata title (or community title) has never seriously been put forward as an option for communities on Aboriginal land, although it was the subject of an article in 2007: see Lewis Shillito, 'Strata Title Aboriginal Towns? An Alternative to the Town-Leasing Proposal' (2007) 14 Australian Property Law Journal 201.

25 For example, it has been argued that one advantage of introducing home ownership through leases rather than freehold is that leases can create a closed market to maintain the 'demographic integrity' of communities: see Evidence to Agriculture, Resources and Environment Committee, Parliament of Queensland, Brisbane, 6 August 2014, 1 (Tim Wishart, Principal Legal Officer, Queensland South Native Title Services). Closed markets are not possible with ordinary freehold title. 
sits towards the left of the spectrum. Under an occupier-driven approach, the focus is instead upon providing the occupiers with a valuable set of property rights that they can exploit to their benefit, such as a freehold or lease towards the right of the spectrum. There is of course a tension between the two approaches - it is not possible to simply do both. Most government statements convey the impression that township leasing is being used to introduce an occupier-driven approach. The following section, which identifies outcomes under the Wurrumiyanga township lease, shows that this is not the case. While there is variation between the different types of infrastructure, for the most part township leases have been used to implement a landowner-driven approach to development.

\section{WURRUMIYANGA TOWNSHIP LEASE}

\section{A The Introduction of Township Leasing}

Around 45 per cent of the Northern Territory is Aboriginal land held under the Aboriginal Land Rights (Northern Territory) Act 1976 (Cth) ('ALRA'). ${ }^{26}$ This means that the Northern Territory has by far the greatest proportion of Indigenous land ownership of any jurisdiction in Australia. In New South Wales, for example, less than one per cent of the state is Aboriginal land. ${ }^{27}$ Most Aboriginal land in the Northern Territory has been unaffected by recent reforms. This is because those reforms have focused on residential communities, particularly larger communities. In the Northern Territory, there are 52 communities on ALRA land that generally have a population of more than 100 . It is these communities that are the target of township leasing. While they encompass only a small fraction of all $A L R A$ land, these communities are highly important as they are the places where most people live.

It is described above how residential communities on Aboriginal land typically contain a range of buildings - such as houses, offices, council depots, schools and stores - and in the past most of those buildings were installed without the occupiers obtaining a grant of formal rights, such as a lease. The result was that people and organisations occupied infrastructure under informal tenure arrangements. ${ }^{28}$ At its most basic, a township lease is one model for introducing formal tenure arrangements into such communities, through a headlease and sublease structure. The township lease itself is a long-term, community-wide headlease, and until recently all township leases were held by a body called the

26 Steering Committee for the Review of Government Service Provision, Overcoming Indigenous Disadvantage: Key Indicators 2016 (Productivity Commission, 2016) Table 9A.2.1. Exclusive and non-exclusive native title covers a further 9.1 per cent of the Territory, see Table 9A.2.3.

270.5 per cent of NSW is Indigenous land while a further 0.1 per cent is subject to exclusive or nonexclusive native title: see ibid.

28 There were exceptions, in that some infrastructure was leased and certain other infrastructure occupied by government departments and missions was subject to a statutory right of occupancy. The historical tenure arrangements in communities on Aboriginal land are described in detail at Terrill, Beyond Communal and Individual Ownership, above n 4, ch 4. 
Executive Director of Township Leasing ('EDTL'). ${ }^{29}$ The EDTL then grants subleases over portions of the community to each occupier. Where it collects rent on a sublease, the EDTL first deducts its expenses and then pays the balance to the landowners, the traditional Aboriginal owners.

A key feature of township leasing has been the role played by the EDTL. It has always been possible for the owners of ALRA land to grant leases directly to occupiers, however the Australian government argues that this takes too long and that once a township lease is in place the EDTL can manage the process more efficiently. The major Aboriginal land councils disagree. Pointing to the fact that thousands of lots have been leased directly to occupiers in the last few years, they argue that direct leasing to occupiers can be just as efficient. ${ }^{30}$

The land councils have also expressed concern about the fact that township leases have shifted control over decision-making from the Aboriginal landowners to the EDTL. ${ }^{31}$ This is one reason why - despite considerable effort by the Australian government - there have been so few township leases. Until recently, only three township leases had been granted, all of which were located on the offshore islands. In the first decade of the reforms, there were no township leases on the mainland in the regions administered by the two larger land councils, the Northern Land Council and Central Land Council.

The reason this has changed recently is because there has been a significant shift in government policy. In 2015, the government announced that it would agree to a township lease being held by a 'community entity' rather than the EDTL. ${ }^{32}$. This means that for the first time an Aboriginal organisation, rather than a government statutory body, will hold the headlease and manage the formalisation process. The policy shift has resulted in three further communities agreeing to a township lease: at Gunyangara, ${ }^{33}$ Mutitjulu $^{34}$ and Pirlangimpi. ${ }^{35}$ The township lease at Gunyangara will be held by a corporation representing the Gumatj traditional owners, while the Mutitjulu and Pirlangimpi leases will initially be held by the EDTL with provision made for transfer to a community entity when a corporation has been created that is willing and able to take on the role.

29 Its website can be found at Office of Township Leasing, Australian Government, The Office of Township Leasing < http://www.otl.gov.au>.

30 See, eg, Central Land Council, 'Land Reform in the Northern Territory: Evidence Not Ideology' (October 2013) 18 n 51. The Land Council has also an alternative model based on a headlease to a body called a 'community land corporation': at 30.

31 Ibid 12-13.

32 Nigel Scullion, 'Gunyangara a Step Closer to Township Lease' (Media Release, 31 July 2015) <http:// www.nigelscullion.com/media-hub/indigenous-affairs/gunyangara-step-closer-township-lease >.

33 Nigel Scullion, 'Historic Township Lease for Gunyangara' (Media Release, 18 November 2017) $<$ https://www.nigelscullion.com/media+hub/Gunyangara+township+lease>.

34 Central Land Council, 'Township Leasing Our Way: Mutitjulu Celebrates its Community-driven Model' (Media Release, 16 March 2017) <https://www.clc.org.au/index.php?/media-releases/article/ township-leasing-our-way-mutitjulu-celebrates-its-community-driven-model/>.

35 Nigel Scullion, 'Celebrations on Tiwi Islands for Township Leasing Outcomes' (Media Release, 27 June 2017) https://ministers.pmc.gov.au/scullion/2017/celebrations-tiwi-islands-township-leasingoutcomes $>$. For both Mutitjulu and Pirlangimpi, the township lease will initially be held by the EDTL but provision has been made for it to be transferred to a community organisation when a corporation has been created that is willing and able to take on the role. 
This issue of control over decision making is of considerable significance, but is not the focus of this article. This article is instead concerned with the subleases that have been granted to occupiers, and more particularly to whom they have been granted and upon what terms, with a view to considering the consequences of this for economic development in affected communities. This will continue to be an important issue, regardless of who holds the township lease itself.

\section{B The Wurrumiyanga Community}

The first ever township lease was granted over the community of Wurrumiyanga on 30 August 2007. Formerly called Nguiu, Wurrumiyanga is situated on Bathurst Island, part of the Tiwi Islands off the coast of the Northern Territory to the north of Darwin. It has a population of between 1265 and 1582 people, ${ }^{36}$ most of whom are Tiwi, making it one of the largest remote Aboriginal communities in the Northern Territory. It is the most useful site for a case study of township subleasing practices because it is the community in which implementation of the reforms is most advanced. While it took several years, the process of granting subleases to occupiers is now substantially complete. From reports produced by the office of the EDTL, it appears that same approach to subleasing is being followed in all other township lease communities.

It is described above how not all Aboriginal people who live in residential communities on Aboriginal land are necessarily traditional owners for that particular country. Wurrumiyanga provides an example of this dynamic. In the course of granting the township lease, the regional Aboriginal land council published a list of 250 people who it identified as being the traditional owners for the land on which the community sits. ${ }^{37}$ This means that most Aboriginal people living in Wurrumiyanga are not traditional owners for that land. It needs to be emphasised that the relationship between residence and traditional ownership is complicated and the distinction is not clear-cut. Long-term residence might lead to a person acquiring some rights to the land under traditional law, particularly in some regions. Further, the proportion of residents who are also traditional owners will vary considerably between communities.

One reason this matters is because the ALRA is one of several Australian land rights schemes that provide for ownership of land by the traditional owners (rather than Aboriginal residents as a group) ${ }^{38}$ Consequently, when decisions are made about whether to implement a landowner-driven or occupier-driven approach to economic development, this impacts on not just on the overall level

36 Coordinator-General for Remote Indigenous Services, 'Six-Monthly Report: July - November 2009' (Australian Government, 30 November 2009) 30.

37 The list is contained in Annexure 6 to the township lease for Wurrumiyanga. A copy of the leases is available here: $<$ https://www.otl.gov.au/sites/default/files/nguiu_headlease_final.pdf $>$.

38 Other examples include the Anangu Pitjantjatjara Yankunytjatjara Land Rights Act 1981 (SA) and some Indigenous land in Queensland. By their nature, native title rights are also held by those Indigenous people whose land it is under traditional laws and customs. 
of development, and how it occurs, but also the question of which people stand to benefit and how authority over the control of resource flows is allocated.

\section{To Whom Have Subleases Been Granted?}

In order to explain, in an intelligible manner, to whom subleases have been granted, this section follows the practice of dividing the composition of communities into three categories: residential housing, service providers and enterprises. While not always neat, this distinction helps clarify the make-up of communities and also corresponds with differences in the approach that has been taken to subleasing. 'Residential housing' refers to the houses in which Aboriginal residents live. Nearly all residential housing in Aboriginal communities is social housing, installed by governments and managed by publicly-funded housing providers. Recently, and coinciding with the introduction of land reforms such as township leasing, a small number of Aboriginal residents have purchased their own homes under subsidised home ownership schemes.

The term 'service provider' refers to organisations occupying infrastructure in Aboriginal communities for the purpose of delivering services. This includes government departments, the local council, health services, aged care facilities and training providers. 'Enterprises' refers to organisations that are engaged in business or commerce, such as the supermarket or community store, a garage, visitor accommodation or art centre. ${ }^{39}$

The community of Wurrumiyanga contains around 417 lots, which have been subleased as follows: ${ }^{40}$

\section{Diagram Three: Table of Wurrumiyanga subleases}

\begin{tabular}{|c|c|c|}
\hline Sublease holder & Duration & $\begin{array}{l}\text { Number of } \\
\text { lots }\end{array}$ \\
\hline \multicolumn{3}{|l|}{ Residential Housing } \\
\hline Territory Housing & 60 years & 281 \\
\hline Home owners & 99 years & 16 \\
\hline \multicolumn{2}{|l|}{ Total number of residential housing lots } & 297 \\
\hline \multicolumn{3}{|l|}{ Service providers } \\
\hline Catholic Church & 20 years & 26 \\
\hline Tiwi Islands Regional Council & 20 years & 22 \\
\hline Northern Territory Government & 20 years & 17 \\
\hline Bathurst Island Housing Association & 20 years & 10 \\
\hline $\begin{array}{l}\text { Indigenous Essential Services (NT Government-owned } \\
\text { corporation responsible for power, water and sewerage) }\end{array}$ & 20 years & 8 \\
\hline Calvary Home Care Services & 20 years & 2 \\
\hline
\end{tabular}

The boundaries of each category are not clear cut and may shift over time: for example, a community service might be provided on a for-profit basis, or an enterprise such as a store or art centre might be conducted in a manner similar to a community service. The categories are nevertheless useful for understanding the makeup of communities.

40 Terrill, Beyond Communal and Individual Ownership, above n 4, 182-3. Some numbers have been updated to take account of more recent data. 


\begin{tabular}{|l|l|l|}
\hline Tiwi Training and Employment Ltd & 20 years & 2 \\
\hline Menzies School of Health & 20 years & 1 \\
\hline Red Cross & 20 years & 1 \\
\hline Northern Territory General Practice Education Limited & 20 years & 1 \\
\hline Total number of service provider lots & $\mathbf{9 3}$ \\
\hline Enterprises & 20 years & 7 \\
\hline Mantiyupwi Pty Ltd (owned by traditional owners) & 12 years & 1 \\
\cline { 2 - 3 } & 5 years & 2 \\
\hline Nguiu Ullintjinni Association (store and garage) & 20 years & 8 \\
\hline Tiwi Design (art centre) & 20 years & 3 \\
\hline Nguiu Club Association (licensed bar) & 20 years & 2 \\
\hline Ngaruwanajirri Artists (art centre) & 20 years & 1 \\
\hline Tiwi Enterprises Pty Ltd & 20 years & 1 \\
\hline Renhe (Australia) Investment Group (property developer) & 20 years & 1 \\
\hline Wulirankuwu Trust & 20 years & 1 \\
\hline Total number of enterprise lots & & $\mathbf{2 7}$ \\
\hline TOTAL & $\mathbf{4 1 7}$ \\
\hline
\end{tabular}

During public debate about land reform, it has been said on a number of occasions that township leasing would lead to ownership of property by individuals. For example, former Minister for Indigenous Affairs, Mal Brough, told Parliament that township leasing would create 'a new tenure system for townships on Aboriginal land' that would 'make it significantly easier for individuals to own their own homes and establish businesses' ${ }^{41}$ In a similar vein, John Howard had earlier argued that Indigenous Australians 'should be able to aspire to owning their own home and having their own business' as having 'title to something is the key to your sense of individuality, it's the key to your capacity to achieve, and to care for your family', ${ }^{42}$

In practice, township leasing has not led to ownership of businesses by individuals. It has been accompanied by some home ownership, but only in small numbers. In Wurrumiyanga, there are now 16 houses owned by Tiwi families whereas previously there were none. ${ }^{43}$ The introduction of home ownership in Wurrumiyanga has been discussed elsewhere, ${ }^{44}$ however it is noted here that these 16 grants represent the outcome of a multi-million dollar program. They are not the simple consequence of having a township lease, and there are no reports of home ownership in any of the other communities with a township lease. ${ }^{45}$ Further, 15 of the 16 grants of home ownership in Wurrumiyanga occurred in the first

41 Commonwealth, Parliamentary Debates, House of Representatives, 31 May 2006, 5-6 (Mal Brough).

42 Michelle Grattan, 'Howard Tilts at Title Fight', The Sunday Age (Melbourne), 10 April 2005, 17.

43 Greg Roche, 'Executive Director of Township Leasing: Annual Report 2016-2017' (Annual Report, Office of Township Leasing, Australian Government, 2017) 6.

44 Terrill, Beyond Communal and Individual Ownership, above n 4, 223-7, 228-33; Leon Terrill, 'What Price to Pay? Home Ownership on Aboriginal Land in the Northern Territory' (2013) 8(9) Indigenous Law Bulletin 12.

45 The annual reports of the Executive Director of Township Leasing refer only to home ownership in Wurrumiyanga. 
three years of the township leases. ${ }^{46}$ There has been only one further grant since November $2010 .{ }^{47}$ This suggests that some saturation point has initially been reached, at least while further work is done on the full range of barriers to home ownership in remote communities.

Again, there have been no subleases to individuals beyond these few grants of home ownership. All enterprise subleases are held by corporations and collectives. Nor has there been a shift from 'non-profit community-based businesses' to 'profit-making businesses', as Warren Mundine has argued for. ${ }^{48}$ For the most part, ownership of enterprises has not changed. The same organisations continue to conduct their businesses, now under a sublease.

The exception to this - and it is a significant exception — is that a body called Mantiyupwi Pty Ltd has acquired 10 township subleases. Mantiyupwi is an investment body that is owned by the traditional owners of the land on which the community is situated. ${ }^{49}$ As noted above, in Wurrumiyanga traditional owners are less than one fifth of all community residents (this ratio varies between communities). The subleases to Mantiyupwi reflect the way in which they have used the township leasing process, including the up-front rent they received, to increase their economic stake in the community..$^{50}$ In the past, it is more likely that such collective businesses would have been owned by an organisation representing the entire community.

It was also suggested during debate about land reform that township leasing might lead to an influx of new businesses, even to the extent that communities are transformed. For example, David Tollner said that under earlier arrangements 'nowhere do you see bakeries. You do not see hairdressers; you do not see clothing stores - let alone a McDonald's or an Irish theme pub', ${ }^{51}$ while the 'normalisation of townships and the creation of long-term leases on towns will enable Aboriginal people and others to buy land and build houses ... [i]t will allow businesses to set up'. ${ }^{52}$ Diagram Three illustrates the extent to which the economies of remote Aboriginal communities are dominated by government-funded service providers. There are only 27 lots subject to an enterprise sublease, as opposed to 93 lots subleased to a service provider and 281 lots subleased to Territory Housing. Township leasing has permanently altered arrangements around land use, and developments accompanying the introduction of township leasing have led to

51

Terrill, 'What Price to Pay?', above n 44, 14.

The most recent was on 14 March 2017: see Roche, above n 43, 16.

Mark Metherell, 'Land System Holds Us Back, Says Mundine', The Sydney Morning Herald (Sydney), 7 December 2004, 6. See also Nyunggai Warren Mundine, 'Procurement Key to Indigenous Growth: Poverty', Australian Financial Review (Sydney), 9 November 2015, 39.

49 See Tiwi Land Council, 'Information for Tiwi Land Owners: Mantiyupwi — Good Business Amongst the Community' (Community Flyer) <http://www.tiwilandcouncil.com/documents/publications/ landowner-info-sheets/Info\%20Doc\%20-\%20Mantiyupwi.pdf>.

50 Terrill, Beyond Communal and Individual Ownership, above n 4, 242-4.

Commonwealth, Parliamentary Debates, House of Representatives, 19 June 2006, 93 (David Tollner).

Ibid. 
some new enterprises (see below), however the fundamental economic character of the community has not changed as a result of township leasing.

\section{On What Terms Have Subleases Been Granted?}

\section{How Does Home Ownership Occur?}

In several respects, the home ownership subleases - that is, the 16 subleases granted to Aboriginal residents under a home ownership scheme - are different to all other township subleases. As depicted below, they are the most freeholdlike, in that they provide occupiers with a commodifiable set of property rights, particularly to the extent that they are long-term and rent-free.

Diagram Four: Home Ownership Subleases

\begin{tabular}{|l|lll|}
\hline Duration & $\begin{array}{l}\text { Short } \\
\text { term }\end{array}$ & $\longrightarrow$ & $\longrightarrow$ \\
$\begin{array}{l}\text { Ongoing } \\
\text { rent }\end{array}$ & Market rent & $\longrightarrow$ & $\begin{array}{l}\text { Long } \\
\text { term }\end{array}$ \\
\hline Transferability & No transfer & $\longrightarrow$ & No rent \\
\hline Restrictions & Many restrictions & $\longrightarrow$ & $\begin{array}{l}\text { Freely } \\
\text { transferable }\end{array}$ \\
\hline Forfeiture & Readily cancelled & $\longleftrightarrow$ & No restrictions \\
\hline
\end{tabular}

In certain other respects, home ownership subleases are more restrictive than might be expected. They can only be sold, underleased or otherwise transferred to another with the consent of the EDTL, and subject to such conditions as the EDTL may impose, although the EDTL may not unreasonably withhold consent (clause 12 of the sublease terms ${ }^{53}$ ). Further, they cannot be sold where to do so would mean that the non-Tiwi population of Wurrumiyanga exceeds 15 per cent (Annexure A, item A.5), although this is not currently an issue as the non-Tiwi population is below 10 per cent. ${ }^{54}$ There is also a range of other restrictions on use. The sublease holder must maintain certain insurance (clause 16), allow the EDTL to enter the premises to conduct inspections (clause 8.2), must only use the land for the purpose of a residential dwelling (clause 9.1) and where requested must remove certain improvements upon expiration of the sublease (clause 20.10). The sublease can also be terminated where the sublease holder abandons the property (clause 20.5). Despite these restrictions, the home ownership subleases are appropriately structured as a form of property to enable them to be mortgaged. All have been mortgaged to Indigenous Business Australia, which provides the home loans under the Indigenous Home Ownership program. ${ }^{55}$

53 The home ownership subleases use a set of standard terms. The author obtained copies through a title search.

54 Greg Roche, 'Executive Director of Township Leasing: Annual Report 2010-2011' (Annual Report, Office of Township Leasing, Australian Government, 2010) 27.

55 The mortgages to Indigenous Business Australia are registered and appear on a title search. 


\section{What About Other Housing?}

Beyond home ownership, other areas of residential housing have been subleased long-term to Territory Housing, the Northern Territory government's public housing provider. Territory Housing then issues residents with tenancy agreements under which they are required to adhere to public housing standards or face eviction. This is not an economic development measure, rather the implementation of a new, stricter and more formalised housing management regime, a development that affects all larger communities on Aboriginal land and not just township lease communities. ${ }^{56}$ The rent paid by residents of public housing does not flow through to the Aboriginal landowners; it is retained by Territory Housing for housing management. The sublease between EDTL and Territory Housing is itself rent-free, as this was the government policy at the time the sublease was granted..$^{57}$

\section{What is the Form of Tenure Granted to Businesses?}

Of greater interest for an article on economic development is the form of tenure granted to businesses. The emergence of new enterprises in Wurrumiyanga has been impressive, in a way that is not immediately apparent from the list of subleases provided in Diagram Three. The land council and the traditional owners have used the township leasing process to set in train a number of developments. This is not entirely new: Tiwi landowners have a history of pursuing economic development opportunities, with the assistance of the land council, most notably through an acacia plantation on the islands. ${ }^{58}$ In the period since the township lease, they have increased their commercial activities within the Wurrumiyanga township, which is new. This has included:

- $\quad$ purchasing an established business called Tiwi Tours;

- $\quad$ entering into a joint venture with respect to a takeaway store;

- $\quad$ acquiring three facilities that provide accommodation to visitors;

- $\quad$ establishing a car-rental business;

56 See Nadia Rosenman and Alex Clunies-Ross, 'The New Tenancy Framework for Remote Aboriginal Communities in the Northern Territory' (2011) 7(24) Indigenous Law Bulletin 11. While the new arrangements impose higher obligations on tenants (see Terrill, Beyond Communal and Individual Ownership, above n 4, 196-7, 233-5) they also provide them with formal rights against the government (see, eg, Shuba Krishnan and Katherine Gregory, 'Anger over Northern Territory Aboriginal Living Conditions Sparks Legal Action, Inquiry Call', ABC News (online), 11 February $2016<\mathrm{http}: / / \mathrm{www}$. abc.net.au/news/2016-02-10/anger-over-nt-town-camps-sparks-legal-action/7157888>; Elly Patira, 'Cuts Both Ways:

Tenants' Rights and the Double-Sided Consequences of "Secure Tenure" in Remote Aboriginal Communities', (2016) 8(23) Indigenous Law Bulletin 3.

57 Calma, 'Native Title Report 2009', above n 10, 139-40. As the sublease to Territory Housing is rentfree, the EDTL does not obtain rent to pass onto the Aboriginal landowners. It is otherwise for most other township subleases, which are subject to rent.

58 Tiwi Land Council, 'Information for Tiwi Land Owners: The Forests of Tiwi Islands — On the Road to Success' < http://www.tiwilandcouncil.com/documents/publications/landowner-info-sheets/ Info $\% 20$ Doc $\% 20-\% 20$ Forest.pdf $>$. 
- $\quad$ purchasing a truck, which it leased to the Bathurst Island Housing Association so that it could take advantage of government construction contracts; and

- $\quad$ constructing a shopping centre..$^{59}$

The Australian government, the EDTL and the Tiwi Land Council have all pointed to these developments as showing the value of township leasing. ${ }^{60}$ This claim requires some examination, to ensure that the appropriate conclusions are being drawn and that other communities are given accurate information about what it is that has worked at Wurrumiyanga. It is suggested here that there have been four factors that have contributed to these developments.

The first is rent. Upon grant of the township lease, the Australian government paid the traditional owners an up-front rental payment of $\$ 5000000 .^{61}$ This is a considerable sum of money, and unlike most government payments the traditional owners were able to use it in any way they chose. For the most part, they chose to invest it. It appears that the up-front rent enabled the traditional owners to purchase Tiwi Tours and the tip-truck and to construct a house as part of the joint venture with respect to the take away store. It also appears that the rent facilitated or helped with the acquisition of the accommodation facilities and the construction of a shopping centre. ${ }^{62}$

A second factor is difficult to quantify or assess, which is that of advice and leadership. It appears that there has been strong leadership from senior traditional owners with respect to pursuing commercial opportunities. Traditional owners have also received assistance with their investments from the land council and from the EDTL. These sorts of investments require expertise that is not always available in remote communities. Some of the developments - such as the construction of the supermarket complex and the acquisition of accommodation facilities - required a high level of strategy and planning.

A third factor is that the Northern Territory Emergency Response and the Strategic Indigenous Housing and Infrastructure Program ('SIHIP') led to a sharp increase in government spending between 2007 and 2011. This is reflected in visitor numbers to the community, which went from around 2500 in 2005 to more than 7000 in 2008, before returning to less than 2000 in $2013 .{ }^{63}$ This led to

59 See Pat Watson, 'Executive Director of Township Leasing: Annual Report 2009-2010' (Annual Report, Office of Township Leasing, Australian Government, 2010) 13; Tiwi Land Council, 'Mantiyupwi - Good Business Amongst the Community', above n 49.

60 See, eg, Scullion, 'Reform for the Future', above n 2; Office of Township Leasing, Australian Government, Benefits of a Township Lease - Case Study - Mantiyupwi Pty Ltd, Office of Township Leasing <https://www.otl.gov.au/township-leases/benefits-township-lease>; Tiwi Land Council, 'Community Flyer: Mantiyupwi — Good Business Amongst the Community', above n 49.

61 This is set out in clause 51(b)(i)(A) of the township lease for Wurrumiyanga, a copy of which is available at $<$ https://www.otl.gov.au/sites/default/files/nguiu_headlease_final.pdf $>$.

62 See Tiwi Land Council, 'Community Flyer: Mantiyupwi - Good Business Amongst the Community', above n 49; Roche, 'Executive Director of Township Leasing: Annual Report 2016-2017', above n 43, 5.

63 Tiwi Land Council, 'Tiwi Land Council 2012/2013: Thirty-Fourth Annual Report' (9 September 2013) 14-15. 
a mini-construction boom, and the traditional owners and land council have been astute in taking advantage of this. For example, Mantiyupwi obtained a number of subleases for the purpose of providing contractors with accommodation while working on SIHIP, ${ }^{64}$ and underleased one area to the Territory Alliance Partners to construct a camp under an arrangement that gave them first option to purchase the assets from the Northern Territory government once construction had been finalised. ${ }^{65}$ This also relied on the government being receptive to this form of development, which has not always been the case. ${ }^{66}$

The fourth factor — which is the focus of this article — is changes to land tenure as a result of the township lease. Previously, the usual practice was for enterprises not to have a lease or sublease. They occupied the infrastructure that they had built or been allocated under informal arrangements. Now they all hold a sublease, and the following table sets out the rent, duration and permitted use for each sublease: ${ }^{67}$

\section{Diagram Five: Enterprise subleases}

\begin{tabular}{|l|l|l|l|l|l|}
\hline Sublease holder & $\begin{array}{l}\text { No. of } \\
\text { lots }\end{array}$ & $\begin{array}{l}\text { Rent per } \\
\text { year }\end{array}$ & Duration & $\begin{array}{l}\text { Renew } \\
\text { option? }\end{array}$ & Permitted use \\
\hline Mantiyupwi Pty Ltd* & 1 & $\$ 11470$ & 20 years & Yes & $\begin{array}{l}\text { Office and staff } \\
\text { accommodation }\end{array}$ \\
\hline Mantiyupwi Pty Ltd & 1 & $\$ 5735$ & 20 years & Yes & Office accommodation \\
\hline Mantiyupwi Pty Ltd & 1 & $\$ 11470$ & 20 years & Yes & Tourist accommodation \\
\hline Mantiyupwi Pty Ltd & 1 & $\$ 11470$ & 20 years & Yes & $\begin{array}{l}\text { Office and staff } \\
\text { accommodation }\end{array}$ \\
\hline Mantiyupwi Pty Ltd & 1 & $\$ 21065$ & 20 years & Yes & $\begin{array}{l}\text { Motel and worker's } \\
\text { accommodation }\end{array}$ \\
\hline Mantiyupwi Pty Ltd & 1 & $\$ 2860$ & 20 years & Yes & $\begin{array}{l}\text { Residential accommodation } \\
\text { for employees and contractors }\end{array}$ \\
\hline Mantiyupwi Pty Ltd & 1 & $\$ 3718$ & 5 years & No & Short term accommodation \\
\hline Mantiyupwi Pty Ltd* & 1 & $\$ 3718$ & 5 years & No & Short term accommodation \\
\hline Mantiyupwi Pty Ltd & 1 & $\$ 2302$ & 20 years & Yes & Residential accommodation \\
\hline Mantiyupwi Pty Ltd* & 1 & $\$ 38500$ & 12 years & No & Supermarket and retail outlet \\
\hline Nguiu Ullintjinni & 1 & $\$ 3718$ & 20 years & Yes & Residential dwelling \\
\hline Nguiu Ullintjinni & 1 & $\$ 3718$ & 20 years & Yes & Residential dwelling \\
\hline Nguiu Ullintjinni & 1 & $\$ 3718$ & 20 years & Yes & Residential dwelling \\
\hline Nguiu Ullintjinni & 3 & $\$ 100000$ & 20 years & Yes & $\begin{array}{l}\text { Nguiu store, café / restaurant, } \\
\text { workshop, fuel bowser }\end{array}$ \\
\hline Nguiu Ullintjinni & 1 & $\$ 3718$ & 20 years & Yes & Residential dwelling \\
\hline
\end{tabular}

64 Watson, above n 59, 13.

65 Ibid.

66 The Office of Township Leasing tried to help Aboriginal organisations in other township lease communities to construct accommodation for sublease to the Northern Territory Government, however negotiations failed because the parties were not able to agree on suitable rent: Greg Roche, Submission to Expert Indigenous Working Group, Investigation into Indigenous Land Administration and Use, June 2015, 5.

67 This information was collated from a title search (through the Land Titles Office of the Northern Territory) of all registered subleases to commercial enterprises in Nguiu/Wurrumiyanga (NT Portion 1640) conducted in 2015. In some cases the amount of rent ramped up over the first few years, and the figures here reflect the final amounts. As described below, most subleases also contain rent review clauses which may lead to further increases. 


\begin{tabular}{|l|l|l|l|l|l|}
\hline Nguiu Ullintjinni & 1 & $\$ 3718$ & 20 years & Yes & Residential dwelling \\
\hline Tiwi Design & 2 & $\$ 3201$ & 20 years & Yes & $\begin{array}{l}\text { Office premises / showroom, } \\
\text { workshop }\end{array}$ \\
\hline Tiwi Design & 1 & $\$ 3718$ & 20 years & Yes & Residential dwellings \\
\hline Nguiu Club & 1 & $\$ 4290$ & 20 years & Yes & $\begin{array}{l}\text { Residential accommodation } \\
\text { for the sublessee's employees }\end{array}$ \\
\hline Nguiu Club & 1 & $\$ 55000$ & 20 years & Yes & $\begin{array}{l}\text { The operation of an associated } \\
\text { social club }\end{array}$ \\
\hline Ngaruwanajirri & 1 & $\$ 10348$ & 20 years & Yes & $\begin{array}{l}\text { Office, showroom, workshop } \\
\text { and manager's residence }\end{array}$ \\
\hline Tiwi Enterprises & 1 & $\$ 9350$ & 20 years & Yes & Workshop/Garage \\
\hline Renhe & 1 & $\$ 3080$ & 20 years & Yes & Residential accommodation \\
\hline Wulirankuwu & 1 & $\$ 3410$ & 20 years & Yes & Residential accommodation \\
\hline Total rent for enterprises & $\$ 323295$ (including GST) & \\
\hline
\end{tabular}

All but one of these enterprise subleases (see below) are subject to a rent-review clause under which every five years the parties must either agree on a new amount or ask the president of the Australian Property Institute to determine the 'open market rental value' of the premises, whose determination then binds the parties. This suggests that the rent for all of these subleases is, or over time will become, market rent. ${ }^{68}$ The enterprise subleases also utilise a set of standard terms and conditions in a similar manner to the home ownership subleases described above. They can only be used for the identified permitted use, and may only be sold, underleased or otherwise transferred to another with the consent of the landowners and the EDTL (clause 9). There are several other restrictions on use, including a requirement that sublease holders maintain improvements (clause 27).

On a number of occasions, the government has argued that part of the economic value of township leases is that they lead to long-term and transferable subleases. The White Paper on Developing Northern Australia refers to township leasing as one option for facilitating 'the tradability and bankability of rights and interests in Aboriginal land'. ${ }^{69}$ In the course of explaining the value of township leasing, Nigel Scullion has referred to the need for 'long term and transferable subleases' of the type that 'you or I could go to the bank with and get mortgage on'.70 More broadly, under its 'Jobs, Land and Economy Programme' the government seeks to fund activities 'that support long-term, tradable tenure'. ${ }^{71}$

These statements suggest that subleases granted to enterprises under a township lease are similar to leases found in the Australian Capital Territory: long-term, transferable and freehold-like. That is not the case. The terms of these enterprise

68 Information included in some of the subleases suggests that the tenants have initially been given a grace period of below-market rental until the first review, particularly the subleases to Nguiu Ullintjinni and the Nguiu Club where it appears likely that the amount of rent will increase after review. This may have now occurred: as described below at $n 80$, the township lease revenue for Wurrumiyanga increased significantly in 2015-16. The updated rental figures are not on the public record.

69 Australian Government, 'Our North, Our Future', above n 1, 31.

70 Nigel Scullion, '2014 National Native Title Conference Speech' (Speech delivered at the 2014 National Native Title Conference, Coffs Harbour, 2 June 2014)

71 Australian Government, 'Indigenous Advancement Strategy Guidelines' (July 2014) $12<$ https:// www.pmc.gov.au/sites/default/files/publications/ias_guidelines.pdf $>$. 
subleases are more like a retail lease that might be found in a shopping centre. In terms of the leasehold spectrum, the average enterprise sublease can be depicted as follows:

\section{Diagram Six: Enterprise Subleases}

\begin{tabular}{|c|c|c|c|}
\hline Duration & $\begin{array}{l}\text { Short } \\
\text { term }\end{array}$ & $\longleftrightarrow$ & $\begin{array}{l}\text { Long } \\
\text { term }\end{array}$ \\
\hline $\begin{array}{l}\text { Ongoing } \\
\text { rent }\end{array}$ & Market rent & $\stackrel{\longleftrightarrow}{\longleftrightarrow}$ & No rent \\
\hline Transferability & No transfer & $\longleftrightarrow$ & Freely transferable \\
\hline Restrictions & Many restrictions & $\longleftrightarrow$ & No restrictions \\
\hline Forfeiture & Readily cancelled & $\longleftrightarrow$ & Can't be cancelled \\
\hline
\end{tabular}

In other words, and in contrast to the home ownership subleases, they have not been designed in a way that facilitates their 'tradability and bankability'. The focus is instead upon providing landowners with rent and a degree of ongoing control. In 2010, then Coordinator-General for Remote Services, Bob Beadman, provided a copy of the standard sublease terms to the Commonwealth Bank and sought advice on their suitability for a mortgage. He was advised that the sublease terms were 'so onerous at [sic] to make the [sub]lease near to valueless and arguably it becomes a business liability rather than an asset'. ${ }^{72}$ The above diagram illustrates why this is the case.

For the most part, those subleases have not been mortgaged or used as collateral for a loan. There is an exception: as the government and the EDTL have pointed out, ${ }^{73}$ part of the funds for the supermarket complex were provided through a commercial loan from Westpac bank that was secured by a mortgage. The mortgage covers three subleases, the supermarket complex and two other buildings used for 'office and staff accommodation' and 'short term accommodation' (those subleases marked with an asterisk in the table at Diagram Five). This indicates that Westpac was of the view that the subleases were not a liability, that despite the obligation to pay ongoing rent they represented positive value.

It is noteworthy that the 12-year sublease for the supermarket complex is different from other enterprise subleases, in that it does not contain a market rent review clause. This is significant, as it is likely that the rental of $\$ 38500$ does not reflect the full value of the sublease. The supermarket complex contains a profitable supermarket as well as four smaller retail spaces, which have been underleased to a takeaway food outlet, a laundromat, a games parlour and a credit union. ${ }^{74}$ It is very likely that this would generate an income for the sublease holder of far more than $\$ 38500$. Other enterprise subleases have been drafted so that any increases

72 Bob Beadman, 'Northern Territory Coordinator General for Remote Services: Report \#2: December 2009 to May 2010' (Department of Housing, Local Government and Regional Services, Northern Territory Government, June 2010) 76.

73 Scullion, 'Reform for the Future', above n 2; Roche, Submission to Expert Indigenous Working Group, above n 66, 3.

74 Roche, Submission to Expert Indigenous Working Group, above n 66, 3. 
in the value of the property are captured through the rent review process and flow to the landowners. There are no other mortgages of an enterprise sublease in Wurrumiyanga, and no reports from other township lease communities. The arrangements for the supermarket complex appear to be exceptional presumably because the sublease holder is Mantiyupwi, which is owned by the traditional owners - rather than representing the first example of what will become a widespread practice. What is actually widespread is the practice of using the subleasing process to generate income for the landowners.

It must be noted that a similar approach to leasing is being taken in communities on Aboriginal land that do not have a township lease. As a result of the recent changes in government policy, and pressure on landowners to grant more leases, enterprises in communities on Aboriginal land across the Northern Territory are expected to sign up to leases and pay 'fair rent'. ${ }^{75}$ This reflects a key element of the new approach that is being taken to land tenure in communities on Aboriginal land. Traditional owners are being given greater social license to exploit their landownership for commercial gain, something that in the past was generally not considered appropriate inside of residential communities.

\section{COMPARING THE TWO APPROACHES}

\section{A Which Is the Best Approach to Land Reform?}

There is legitimate scope for debate about whether a landowner-driven approach or an occupier-driven approach is better suited to the needs and circumstances of remote communities on Indigenous land. While township leasing and related reforms have been underway for a decade, we have never had such a debate. This section considers, in broad terms, some of the consequences of different approaches. It is acknowledged here that the terms 'landowner-driven' and 'occupier-driven' development are simplifications. The leasehold spectrum makes clear how there is a range of possibilities and the potential for mixed outcomes: for example, a lease might be long-term and rent-free, but inalienable. There is nevertheless a fundamental tension between the two approaches. It is also the case that the preferred approach will differ, depending as it does on the preferences and circumstances of each community and the type of infrastructure under consideration. Already in Wurrumiyanga there is a mixture: home ownership subleases reflect an occupier-driven approach while other subleases are more consistent with a landowner-driven approach.

To be clear, this is not a situation where the outcome can be left to 'market forces' or for Aboriginal people to decide for themselves. The role of Aboriginal landowners and Aboriginal community residents in the decision-making process

75 Central Land Council, 'Application for a Lease, Licence or Other Interest in Aboriginal Land', $2<$ http://www.clc.org.au/files/pdf/Leasing_application_form.pdf $>$. See also Terrill, Beyond Communal and Individual Ownership, above n 4, 199. 
is critical; the importance of this cannot be understated. However, it is neither possible nor desirable to simply 'leave it to them'. Governments and organisations such as Aboriginal land councils are inextricably involved. The approach that they take to applying for or requiring (sub)leases, to agreeing to or requiring rent, to deciding which communities are eligible for home ownership programs and which communities will receive funding - these will heavily influence, if not shape, the outcome. In such circumstances, purporting to 'leave it to the community' can conceal the influence that governments and other organisations have. This is also a complex and novel situation, one in which any community would benefit from access to the best available information and advice. Further, this article demonstrates how at times there is the potential for conflict between the interests of traditional landowners and non-landowner residents. Where it occurs, the approach taken by outsiders will influence the resolution (or exacerbation) of this conflict.

\section{B A Landowner-Driven Approach to Economic Growth}

Under a landowner-driven approach, the focus is on obtaining an economic return for the landowners, primarily through rent. For the past few decades, most businesses and organisations that operated in Aboriginal communities did not pay rent for the land they occupied. In Wurrumiyanga, for example, prior to the township lease the landowners were receiving just $\$ 2000$ per year from rent on leases within the community. ${ }^{76}$ This has changed dramatically. Since 2013, the office of the EDTL has been publishing the amount of revenue it collects each year in its annual reports. For the Wurrumiyanga township lease, that amount has been $\$ 642219,,^{77} \$ 715822,{ }^{78} \$ 668677,,^{79} \$ 1169151,{ }^{80}$ and $\$ 1038576 .^{81}$ Initially, that rent went towards repaying the $\$ 5000000$ up-front payment that was made to landowners upon grant of the township lease. That amount has now been repaid, which means that future rent will be 'disbursed to organisations nominated by the Mantiyupwi Traditional Owners for their ongoing economic and social development' 82

Rent is a source of income for landowners and an additional cost for occupiers, and some of the consequences of this are explored below. It must be noted that the introduction of rent is a development that extends beyond township leases: in

77 Greg Roche, 'Executive Director of Township Leasing: Annual Report 2012-2013' (Annual Report, Office of Township Leasing, Australian Government, 2013) 20.

78 Greg Roche, 'Executive Director of Township Leasing: Annual Report 2013-2014' (Annual Report, Office of Township Leasing, Australian Government, 2014) 23.

79 Greg Roche, 'Executive Director of Township Leasing: Annual Report 2014-2015' (Annual Report, Office of Township Leasing, Australian Government, 2015) 23.

80 Greg Roche, 'Executive Director of Township Leasing: Annual Report 2015-2016' (Annual Report, Office of Township Leasing, Australian Government, 2016) 30. The report does not explain or comment on the significant jump in income between this and the previous financial year, which may be due to rent review mechanisms in subleases: see above $\mathrm{n} 68$.

81 Roche, 'Executive Director of Township Leasing: Annual Report 2016-2017', above n 43, 34.

82 Ibid 5. 
communities on Aboriginal land across the Territory, there has been a significant increase in the amount of rent being collected. There is no research or published reports that detail whether rental rates are higher or lower in communities with a township lease. And while the amount of rent is not inconsiderable, it is also necessary to put these figures in context. Wurrumiyanga is one of the largest communities on Aboriginal land, with a population of between 1265 and 1582 and around 250 traditional owners. ${ }^{83}$ In most other communities the rent will be less. This rent is not enough to completely change the economic environment, and it will take considerable skill to use/invest it in a way that has a real impact. Conversely, the extent of the additional cost to occupiers should not be overstated. Many of the enterprises described above are paying just a few thousand dollars a year in rent. ${ }^{84}$ In some cases it is much larger, however this appears to be for enterprises (the social club, the store and café) that are more profitable.

\section{Rent as Landowner Income}

\section{(a) The Different Uses towards Which Rent Can Be Put}

Rent is paid to the Aboriginal landowners collectively. In general terms, they then have a choice whether to invest it, to use it on community projects or to distribute it to individuals and families. Different issues arise in each case. Where rent is invested, then (depending on the availability of suitable investments) the landowners will receive further returns down the track. As the experience in Wurrumiyanga demonstrates, investment can also occur in ways that have other impacts. The landowners have invested in enterprises in the community, creating the opportunity for jobs and for individuals to acquire greater skills and expertise. Such investments can also result in community residents having access to facilities and services that were not available previously.

Where rent is used on community projects - such as support for sporting clubs, schools, art centres, outstations and infrastructure such as basketball courts and workshops - there is again a clear benefit to the community. It is not known what percentage of the Wurrumiyanga rent has been used on community projects (and this might be regarded as confidential). Further south, the Central Land Council has reported that between 50 and 100 per cent of the rent that landowners received for the 'five-year leases' (introduced as part of the Northern Territory Emergency Response) will be applied to community benefit projects. ${ }^{85}$ It is not just the organisations receiving funds that benefit from these processes: where done well, the processes associated with selecting and implementing projects can provide opportunities for community planning, the expression of autonomy and

83 Coordinator-General for Remote Indigenous Services, above n 36, 30; Wurrumiyanga Township Lease, Annexure $6<$ https://www.otl.gov.au/sites/default/files/nguiu_headlease_final.pdf $>$.

84 See Diagram Five above.

85 Danielle Campbell and Janet Hunt, 'Making Use of Payments: A Community Development Model' in Sean Brennan et al (eds), Native Title from Mabo to Akiba: A Vehicle for Change and Empowerment? (Federation Press, 2015) 229, 239. 
the development of leadership. ${ }^{86}$ Community development processes can also overtly cater to the position of vulnerable groups within communities and can ensure that matters such as gender are not overlooked.

Payments from the landowning group to individuals can take a number of forms. At their simplest, they can be distributions of cash or other benefits - a practice that has historically been common with respect to royalties and other payments on Aboriginal land. They can also be targeted at particular categories of need: where, for example, payments are made to 'sick and elderly family members' or 'to students and patients travelling interstate'. ${ }^{87}$

\section{(b) The Characterisation of Rent}

One issue here is whether or not rent should be characterised as a constructive form of income. Debate about welfare dependence and the long-term impact of transfer payments and subsidised benefits in Aboriginal communities has popularised the concern that some forms of income can be harmful as well as helpful, an idea captured by terms such as 'harmful welfare'. It has been argued by some that paying rent and other royalties to Aboriginal landowners is another form of harmful welfare. For example, Beadman has argued that rent on township subleases creates 'a passive "royalty" flow for Traditional Owners' rather than facilitating 'a property market for the long-term benefit of all residents' ${ }^{88}$ Nicolas Peterson asks: 'Should the traditional owners of the townships be turned into a rentier class or should their interests be bought out?' ${ }^{89}$ In a related context, Andrew Forrest has argued that making untied payments to Aboriginal organisations under native title agreements is a form of 'mining welfare' and 'part of the welfare cycle'. 90

Such statements clearly have the potential to be politically disempowering for Aboriginal landowners. They also appear to correlate the making of payments to Aboriginal organisations with the distribution of those payments to individuals and families. That has been widespread but is not always the case. And as the previous section makes clear, untied payments to Aboriginal organisations can also be empowering and have positive flow-on effects for communities. The 'harmful welfare' characterisation of rent is not a straightforward matter. Further, and as discussed below, it is likely to be collective Aboriginal organisations that benefit most from an occupier-driven approach, rather than individuals. The complex issue of how individuals benefit from the profits of collective organisations will arise in that context as well.

See generally ibid $241-2$.

Tiwi Land Council, 'Mantiyupwi Continues to Make Progress', The Tiwi (online) 20 (June/July 2015), $10<$ http://www.tiwilandcouncil.com/publications/The-Tiwi/2015-July/index.htm>.

Beadman, above n 72, 74.

Nicolas Peterson, 'Community Development, Civil Society and Local Government in the Future of Remote Northern Territory Growth Towns' (2013) 14 Asia Pacific Journal of Anthropology 339, 348.

See, eg, Australian Broadcasting Corporation, 'Iron and Dust', Four Corners, 18 July 2011. 


\section{Rent as an Additional Expense for Occupiers}

On the other side of the equation, rent has increased the costs of doing business in communities on Aboriginal land for enterprises and for services providers. A significant portion of that rent in Wurrumiyanga has been paid by a few key enterprises (the social club and store/café), while around half has been paid for by service providers rather than enterprises. ${ }^{91}$ For most enterprises, the amount of rent is small relative to the other costs of operating in a remote community. While it is possible that that rent might lead to a reduction in commercial investment, currently that risk appears to be small. It is nevertheless possible that rent will have an impact on the development of new enterprises, particularly where the margins are slim. If one aim of land reform is to make it easier for individuals and families to set up enterprises such as a clothes store, hairdresser or laundromat, the imposition of rent makes this more difficult, not easier. This could be avoided through the creation of enterprise zones, an issue discussed further below.

As well as being an additional cost, rent makes it significantly more difficult for occupiers to use their sublease as collateral for a loan. Where rent is above a certain level, a sublease will not be sold for a premium because a prospective purchase will regard the ongoing rental obligations as being equal to or greater than the value of the sublease. And where there is little or no chance of it being sold for a premium, a sublease will not be mortgaged. That is one reason why it is misleading when the Australian government states that township leasing delivers 'long-term tradeable tenure to underpin commercial activities' and 'makes it possible for individuals to obtain long-term subleases to support a loan'. ${ }^{92}$ This is not what happens for the majority of enterprises on a township lease. The next section considers whether enterprises would be likely to use their properties as collateral, even if they were provided with 'long-term, tradable tenure'.

\section{An Occupier-Driven Approach to Economic Growth}

Under an occupier-driven approach, the focus is instead on making it easier to establish and grow enterprises in communities on Aboriginal land by providing people and/or organisations with access to land and a form of property rights that suit their business needs. This, it must be said, is a little complicated. It is clear that an occupier-driven approach is facilitated where the processes for obtaining access to land are quick and uncomplicated, where access to land is cheap, where property rights are long-term and secure and, in some circumstances, where property rights are tradeable such that they can be used as collateral for a loan. What is less clear is how these aims are best achieved in a particular environment, including the question of when an open land market will achieve better outcomes than centralised processes for the allocation and re-allocation of land. In communities outside of Indigenous land, we tend to rely on open

91 See the table in Diagram Five above.

92 Department of the Prime Minister and Cabinet, 'Closing the Gap: Prime Minister's Report 2016', above $\mathrm{n} 5,39$. 
land markets. That does not mean that such markets are equally suited to the very particular economic, demographic and cultural circumstances of remote communities on Indigenous land. Rather than get bogged down in the mechanics of enabling an occupier-driven approach, the discussion here focuses on the use of land as collateral and the potential for enterprise zones.

\section{The Use of Land as Collateral}

An issue that is often raised in this context is that of supporting economic growth by enabling land to be used as collateral for a loan. The discussion provided earlier gives some indication of the sort of lease or sublease that is required for this to occur: one that is not just transferable, but also sufficiently long-term, where the level of rent and other restrictions is such that the lease or sublease is seen as representing positive value rather than a liability. In simple terms, this suggests a lease or sublease to the right of a leasehold spectrum, or a grant of freehold.

It is clear, however, that the extent to which occupiers are able to 'leverage' their property rights depends not just on the nature of those rights but also on market conditions. It is here that a dose of realism is required when discussing remote communities with low income levels and a high reliance on government funding. In Wurrumiyanga, currently most enterprises hold restrictive subleases under which they pay market rent. However, even if those subleases were freehold-like in every respect it is not at all clear that they would be used as collateral for a loan, and that the proceeds of such a loan would then be used to fund new business activities. In fact, such an outcome is optimistic. ${ }^{93}$ The key point is that market conditions impose real constraints on the ability of an occupier-driven approach to deliver benefits to enterprises and to the community.

\section{The Potential for Economic Zones}

On the other hand, a targeted approach to supporting enterprise development might have a real impact on the lives on of least some residents. It is described above how the construction of a new supermarket complex in Wurrumiyanga led to four new retail spaces. It appears that the tenants of those shops are required to pay rent to Mantiyupwi. An alternative might be to make such spaces available at low cost to Aboriginal residents or organisations wishing to start a business. ${ }^{94}$ Initially they would not require a tradable sublease that could be used as collateral; more important would be a sublease that is low cost and sufficiently long-term. Where the aim to is to encourage ownership of businesses by individuals, or small-scale local enterprises, a targeted approach involving support for the construction of appropriate infrastructure and the grant of leases or subleases on accommodating terms is likely to be more effective than the wholesale or community-wide reliance on a particular form of tenure or a naïve reliance on the introduction of 'land markets'. 


\section{DISCUSSION}

\section{A Impact on Overall Levels of Economic Activity}

The table of Wurrumiyanga subleases in Diagram Three of this article provides a snapshot of the nature of economic activity in the community. There are 297 lots allocated to housing, 93 to service providers and just 27 to enterprises. It is enterprises that are the focus of an occupier-driven approach to development, and they are a small portion of the community. Providing service providers with a fee simple or a freehold-like lease or sublease will not have a direct or immediate impact on economic development. On the other hand, charging service providers rent does have such an impact. It provides an income stream for landowners that might be used to facilitate further developments. From the figures above it appears that the rent paid by service providers has been around half of all rent for Wurrumiyanga.

Of course, that rent has to come from somewhere. Nearly all service providers in Aboriginal communities are either government departments or governmentfunded NGOs, and so this rent is provided out of government funding. In the past governments have refused to pay rent for the use of land in Aboriginal communities and one of the biggest changes of the last decade has been that they are now willing to do so. The question of whether they should might be debated: the point for present purposes is that for service providers, taking a landowner-driven approach to development will have a more significant and direct impact on the level of economic activity in communities than would an occupier-driven approach.

For enterprises, the situation is more equivocal. The introduction of rent means that landowners receive a portion of income or profits, albeit a relatively small portion, and enterprise owners receive less. It is also means that occupiers are less able to use their property rights as collateral for a loan. It is more difficult to state whether a landowner-driven or occupier-driven approach is likely to have the greater overall impact on levels of economic activity.

\section{B Who Benefits?}

A key difference between a landowner-driven and occupier-driven approach is with respect to who benefits and how benefits are administered. In township lease communities, rent is ultimately paid to traditional owners rather than, for example, to community residents as a whole. In addition, traditional owners in Wurrumiyanga have used the township leasing process to increase their economic stake in the community through the acquisition and development of several enterprises. There is no evidence that traditional owners have used their position to the detriment of community residents. However, the concern of this article is with township leasing as a structure, how it might apply to other communities or in the future.

Discussing land issues in Aboriginal communities more generally, Peterson points out that 'a real danger is that a small group of traditional owners may 
pursue their economic self-interest to the detriment of the community. ${ }^{95}$ As one of Australia's most experienced anthropologists, and one with a long history of involvement in land rights, Peterson's concerns need to be taken seriously. A risk of taking a landowner driven approach to development on land that is owned traditionally is the potential for a conflict between the interests of traditional owners and (other) residents, and for increased disputation about membership of the traditional ownership group. Where Indigenous land is owned by residents as a whole - as occurs in some other places - this particular issue does not arise.

It is also likely to remain the case that most enterprises in communities on Aboriginal land are owned collectively. The choice between a landowner-driven and occupier-driven approach is not a choice between collective and individual ownership of resource flows. Collectively-owned enterprises face similar issues with respect to the distribution of benefits as those affecting collectively-owned land. The potential for particular families to manipulate leasing processes and enterprise management for their own benefit is not avoided by taking an occupierdriven approach. A difference is that an occupier-driven approach will result in a greater variety of collective organisations that manage resource flows for the benefit of their members.

There is a further difference with respect to processes. Rent is initially administered by Aboriginal land councils, which are relatively large organisations with established processes for managing and distributing payments. Those processes do vary. For Wurrumiyanga, the Tiwi Land Council has helped the traditional owners create and administer investment vehicles such as Mantiyupwi Pty Ltd. Further south, the Central Land Council's Community Development Unit works with landowners to use some rent towards community projects. At other times, land councils instead simply distribute rent to individuals or landowner corporations.

\section{The Relationship between Culture and Economic Development}

While the cultures of Aboriginal communities are constantly evolving in response to the changed circumstances in which people now find themselves, it remains the case that those cultures are distinct. This impacts on the way in which economic activity occurs and is experienced. Examples of this include the persistence of sharing norms, including 'demand sharing', and practices such as asymmetrical reciprocity. ${ }^{96}$ When land tenure reform is debated in terms of a dualism between communal and individual ownership, this lends itself to the suggestion that the impact on culture is clear. Communal property is often regarded as being more consistent with Aboriginal culture while the introduction of individual ownership has been portrayed, positively and negatively, as an agent for cultural change. ${ }^{97}$

96 See, eg, Nicolas Peterson, 'On the Persistence of Sharing: Personhood, Asymmetrical Reciprocity, and Demand Sharing in the Indigenous Australian Domestic Moral Economy' (2013) 24 Australian Journal of Anthropology 166.

97 Terrill, Beyond Communal and Individual Ownership, above n 4, 145-6. 
As the discussion above makes clear, the relationship between land tenure reform and culture is more complicated than this. It is not a straightforward matter to argue that an occupier-driven or landowner-driven approach to development is more compatible with or better suited to the culture of remote communities. It is suggested here that far more detailed research would be required, including research of an empirical nature, before reliable conclusions could be drawn.

\section{CONCLUSION}

A key aim of this article is to rectify misconceptions about the way in which township leases impact on the economic circumstances of communities on Aboriginal land. It is common to find statements to the effect that township leases deliver 'long-term tradeable tenure', ${ }^{98}$ or that '[b]y creating land administration arrangements that deliver transferability equivalent to freehold, township leasing can give confidence to investors and improve the bankability of Indigenous land'. ${ }^{99}$ This article demonstrates why such statements are misleading. The creation of 'long-term tradeable tenure' on township leases is the exception rather than the norm, particularly for enterprises. To date, there has been one reported mortgage of an enterprise sublease, which is the sublease to Mantiyupwi Pty Ltd for the new supermarket complex in Wurrumiyanga. That sublease is notable for the fact that it is different to other subleases; in key respects it is not representative. Other subleases have been drafted so as to maximise returns for landowners. It is very unlikely that the mortgaging of other subleases will become widespread.

This reflects the implementation of a particular approach to land reform, whether or not this was done consciously. In order to better understand the nature of the decisions that have been made, this article introduces the concepts of a leasehold spectrum and an occupier-driven and landowner-driven approach to development. For the most part, and contrary to what has often been suggested, existing township leases implement a landowner-driven approach. The article considers some of the consequences of this. It is not a straightforward matter to argue that one approach is in all circumstances preferable to the other, as there are benefits and drawbacks to each. It is suggested here that a landowner-driven approach is likely to have a bigger impact to the extent that it results in service providers paying rent. On land that is owned traditionally, a landowner-driven approach also results in one group of people (the traditional owners) acquiring a greater economic stake in the community. This is a serious development, one that requires careful consideration. That consideration is only possible if we are clear about the exact way township leases impact on economic activity in communities on Aboriginal land.

99 Senior Officers Working Group, 'Investigation into Indigenous Land Administration and Use: Report to the Council of Australian Governments' (Report, Council of Australian Governments, December 2015) 35 . 